\title{
MULTISENSORS FOR WHOLE-CELL ANALYTICS
}

\author{
Ingo Tobehn-Steinhäuser ${ }^{1}$, Margarita Günther ${ }^{2}$, Stefan Görlandt ${ }^{1}$, Steffen Herbst ${ }^{1}$, Heike Wünscher ${ }^{1}$, \\ Thomas Ortlepp ${ }^{1}$, Gerald Gerlach ${ }^{2}$ \\ ${ }^{1}$ CiS Forschungsinstitut für Mikrosensorik GmbH, ${ }^{2}$ Technische Universität Dresden, Solid-State Electronics Laboratory
}

Abstract: Whole-cell biosensors, which can be used in the environmental protection and process measuring technology, in the biotechnology, food and pharmaceutical industry for the on-line control and monitoring of chemical and biochemical processes and for the fast detection of small amounts of solutes, are of great interest. These kind of biosensors comprise microorganisms like genetically modified yeast cells, which react on a specific stimulus, e.g. a residual amount of drugs in the measurement medium with a dependent fluorescence. The receptors of the cells detect specific signal molecules and stimulate the organism to produce a fluorescent protein. In this work, a combined impedimetric-optical read out was used, which can provide the reliable and long-term stable detection of a fluorescence signal accompanied by impedance measurements monitoring cell vitality and activity. A new challenge thereby is a special sensor design which enables the integration of excitation source, photodetector, interdigitated electrodes, and the fluidic system with an effective and long-term-stable packaging.

Keywords: Diclofenac, impedance spectroscopy, transparent ITO-electrodes, switchable electrical interdigital fingers, multiplexer

\section{MULTISENSORY DLA BIOSENSORÓW PEŁNOKOMÓRKOWYCH}

Streszczenie: Biosensory petnokomórkowe ciesza się bardzo dużym zainteresowaniem. Moga one być wykorzystywane w ochronie środowiska i technologii pomiaru procesów, $w$ branży biotechnologicznej, spożywczej $i$ farmaceutycznej do kontrolowania $i$ monitorowania procesów chemicznych i biochemicznych on-line oraz do szybkiego wykrywania niewielkich ilości substancji rozpuszczonych,. Tego rodzaju biosensory obejmują mikroorganizmy, takie jak genetycznie zmodyfikowane komórki drożdży, które reagują na specyficzny bodziec, np. fluorescencją na resztkowa ilość leków w pożywce pomiarowej. Receptory komórek wykrywaja określone czasteczki sygnałowe i stymuluja organizm do wytwarzania biatka fluorescencyjnego. W pracy wykorzystano tączony odczyt impedancyjno-optyczny, który może zapewnić niezawodna i długotrwale stabilna detekcje sygnału fluorescencyjnego, któremu towarzysza pomiary impedancji monitorujace żywotność i aktywność komórek. Nowym wyzwaniem jest specjalna konstrukcja czujnika, która umożliwia integrację źródła pobudzenia, fotodetektora, elektrod palcowych i układu plynowego w jednej obudowie.

Słowa kluczowe: Diclofenac, spektroskopia impedancyjna, przezroczyste elektrody ITO, przełączane palce elektrodowe, multiplekser

\section{Introduction}

Within the framework of the collaborative project BioSAM, a sensor for the detection of the analgesic diclofenac in wastewater was developed. It was used as a prototype by several institutes that worked on different work packages according to their profile. Of the total drug used, diclofenac reaches $70 \%$ by excretion via the urine in the wastewater cycle. In Germany, only $63 \mathrm{t}$ per year are prescribed medically. In water treatment plants, diclofenac is removed in only insignificant amounts, so that it enters the water cycle [5]. For example, in a 2008 study on European rivers, diclofenac concentrations in the one- to three-digit nanogram per liter range were measured [2]. From India, the fact is known that the uptake of the substance can lead to death of free-living vultures by kidney failure. Some fish species have also been shown to have harmful effects on the liver and kidneys [1].

In practice, there are already very accurate and reliable analytical methods for the detection of diclofenac in surface water. However, they need an infrastructure such as special laboratories with appropriate staff and logistical efforts. In contrast, the method presented here is inexpensive and suitable for on-site measurements.

The functional principle of the developed whole-cell biosensor is based on the use of genetically modified yeast cells, which produce a fluorescent protein under the influence of diclofenac. The detection of a fluorescence signal was accompanied by impedance measurements monitoring both cell vitality and activity.

\section{Experimental setup}

\subsection{Impedance sensor}

In order to enable a combination of optical and electrical measurements, transparent ITO (indium tin oxide; $0.5 \mu \mathrm{m}$ thick) interdigital structures for impedance spectroscopy were coated on the B270i glass wafers (wafer thickness $(1.0 \pm 0.1) \mathrm{mm}$ ). The prepared structures were optically transparent and conductive. The living cells were immobilized on the glass substrate with two coated ITO-electrode arrays in a four-chamber microfluidic cell. The optical transmitter/receiver module was installed below the glass substrate (figures 1 and 2).
Two ITO-electrode arrays provided the independent impedance measurements for the measuring and reference channels. Each array consists of 24 fingers (with a finger length of $11 \mathrm{~mm}$ ). Depending on the layout, the distance between the fingers varies between $2.5 \mu \mathrm{m}$ and $133.5 \mu \mathrm{m}$ and the width between $5 \mu \mathrm{m}$ and $186 \mu \mathrm{m}$ (Fig. 2).

Using a multiplexer, it was possible to connect the finger structures arbitrarily to form arrays or to operate them individually. As a result, the penetration depth of the electric field into the medium could be varied. Thus, the medium and cells could be impedimetrically detected separately from each other [6].

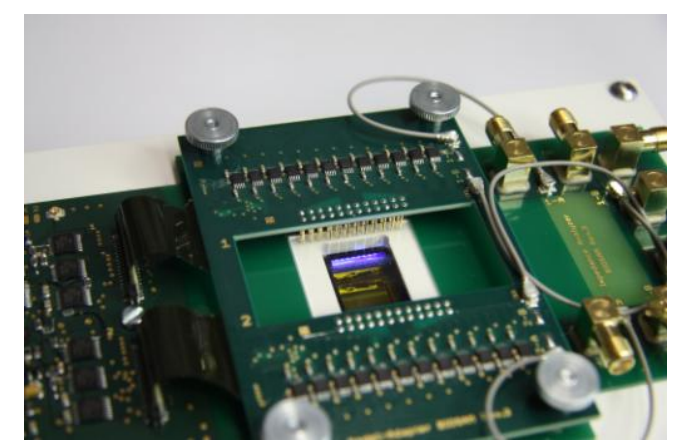

Fig. 1. Circuit board with control-part, multiplexer, interdigital ITO (indium tin oxide) structures and fluorescence sensor for analyte detection (the fluidics interface is not shown)

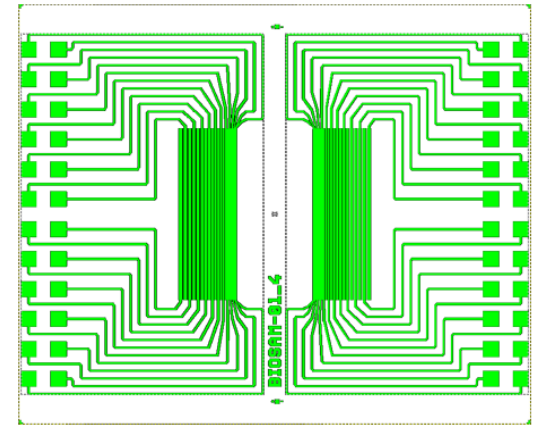

Fig. 2. Layout of the ITO-structures on glass 
The multiplexer board consists of a main board and a needle adapter board. The latter was detachably connected to the main board by two ZIF flex connections. It consists of a $2 \times 12$ dual analog multiplexer, $2 \times 24$ spring contact pins and 4 micro coax connectors [7].

Using a corresponding graphical user interface (GUI), the individual shift registers were controlled via the COM port and the microcontroller in such a way that each of the $2 \times 24$ channels could be switched to high or low (GND, ground) signal separately.

One spring contact pin represents one channel. The needle adapter board is pressed down by means of 4-four knurled nuts/screws so that the spring contact pins are pressed onto the contact surfaces of the BioSAM chip. By switching the channels, individual "strips" or "strip pairs" can be activated or deactivated so that the active measuring area is increasing or decreasing.

The output signal is formed by that contributions from the actively switched channels. All inactive channels were switched to ground (GND) and their signals were thus not recorded and did not contribute to the sum signal.

\subsection{The optical sensor}

The optical sensor consists of two LED light sources (one for each chamber), two filter units and the photodiode (Figs. 3 and 4). The filter units separate the excitation $(470 \mathrm{~nm})$ and the fluorescent $(510 \mathrm{~nm})$ light as sharply as possible.

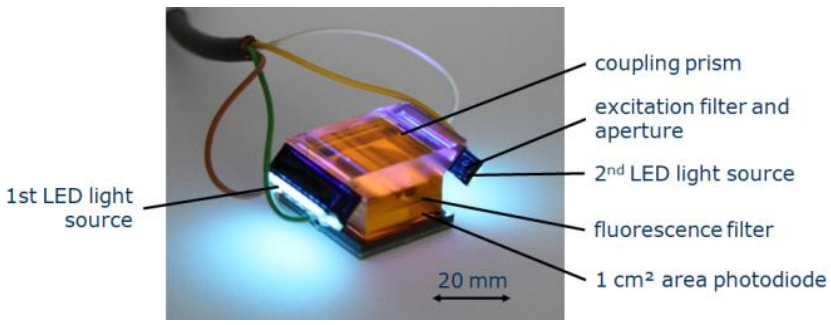

Fig. 3. Optical sensor

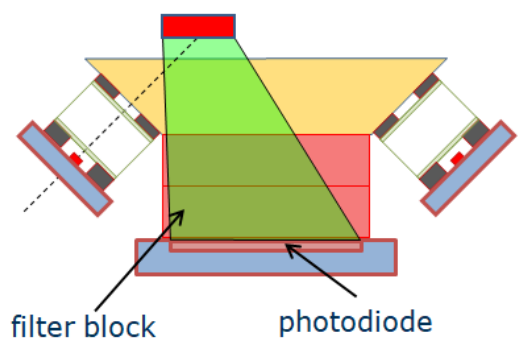

Fig. 4. Schematic cross-section through the optical sensor

\section{Measurement results}

Test measurements were carried out at CiS Forchungsinstitut für Mikrosensorik, Erfurt, for $\mathrm{KCl}$ aqueous solutions by means of a LCR meter 4294A (Agilent Inc.) (Fig. 5). This LCR meter has a measuring range of $40 \mathrm{~Hz}$ to $110 \mathrm{MHz}$ whereas the frequency range amounts only to $40 \mathrm{~Hz}$ to $1 \mathrm{MHz}$.

The measurements were performed for the $\mathrm{KCl}$ solutions with concentrations of $1 \mathrm{~mol} / \mathrm{l}, 10^{-3} \mathrm{~mol} / \mathrm{l}, 10^{-5} \mathrm{~mol} / 1$, and $10^{-7} \mathrm{~mol} / \mathrm{l}$. Since potassium and chloride ions have the same ion mobility those solutions are almost potential-neutral and therefore are preferably used as a calibration standard [4]. Additionally, the impedance spectrum of the dry substrate was recorded (Fig. 5).

For measurements with living cells, one of the two chambers served as a reference with only the nutrient medium flowing through it. The presence of cells affects the measuring impedimetric signal by their electrical properties.

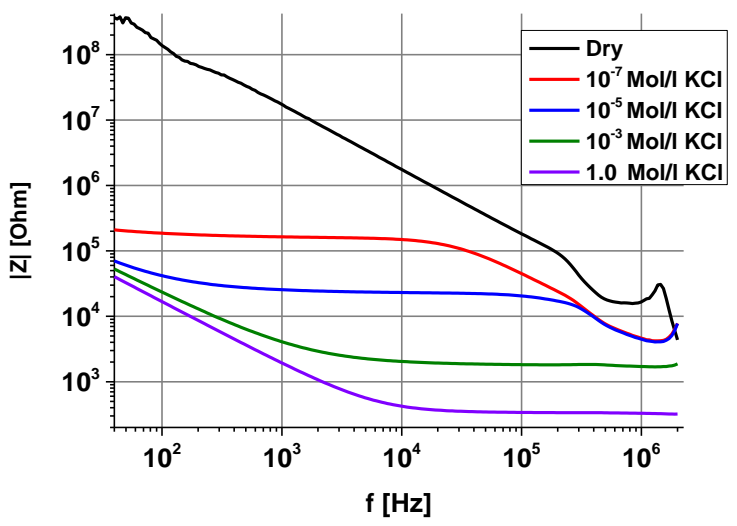

Fig. 5. Impedance spectra for the $\mathrm{KCl}$ solutions and for the dry substrate

In general, a cell can be described quite well by means of a equivalent circuit diagram, in which the cell membrane is characterized by two capacitances and the interior of the cell is modeled by an ohmic resistor.

In the combined opto-impedimetric sensor system, the fluorescence signal was optically detected using the CiS fluorescence setup when switching on either one LED row or two LED rows (470 nm, $27 \mathrm{~V}, 8 \mathrm{~mA})$. The photodiode current was measured by means of a current-voltage converter based on an operational amplifier OP177 and a LabJack U6-PRO card [3].

Figure 6 shows the change of the photodiode current as a function of the diclofenac concentration after a $16 \mathrm{~h}$ overflow with MM (minimal medium nutrient solution), mixed with different diclofenac concentrations. The optical signal was determined using the fluorescence setup, which was located below the microfluidic cell with immobilized yeast cells (Saccharomyces cerevisiae BY4741 p426PDR5-tGFP).

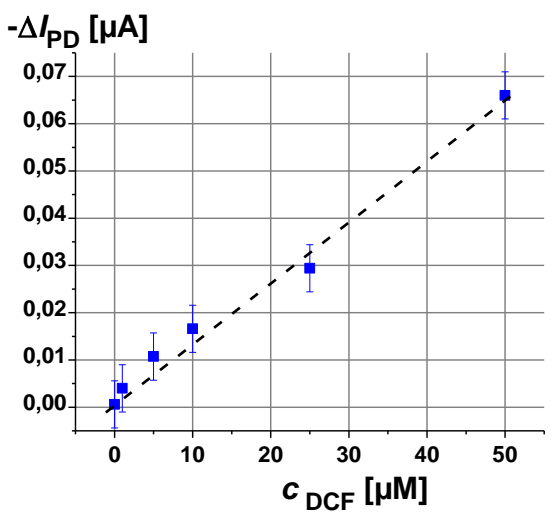

Fig. 6. Photodiode current $I_{P D}$ as a function of the diclofenac concentration $c_{D C F}$

The results of the impedance measurements are shown in figures 7 and 8 . In was found, that the impedance spectrum depends on the electrode configuration, on the composition of the supplied solution as well as on the cell density. Figure 7 compares the spectra for the yeast cells immobilized in gel and for the cell suspension placed on the ITO electrode arrays (glass substrate BioSAM-01_4) in a microfluidic cell. Figure 8 shows the change in the impedance modulus at a frequency of $100 \mathrm{kHz}$ for immobilized yeast cells Saccharomyces cerevisiae BY4741 p426PDR5-tGFP in the medium and in $1 \mu \mathrm{M}$ diclofenac solution. The time-dependent impedance increase was caused by the cell proliferation. 


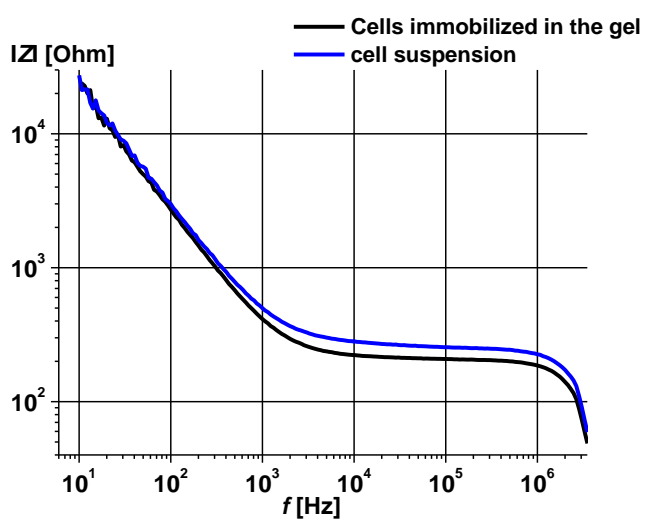

Fig. 7. Impedance spectra for the immobilized cells and for the cell suspension

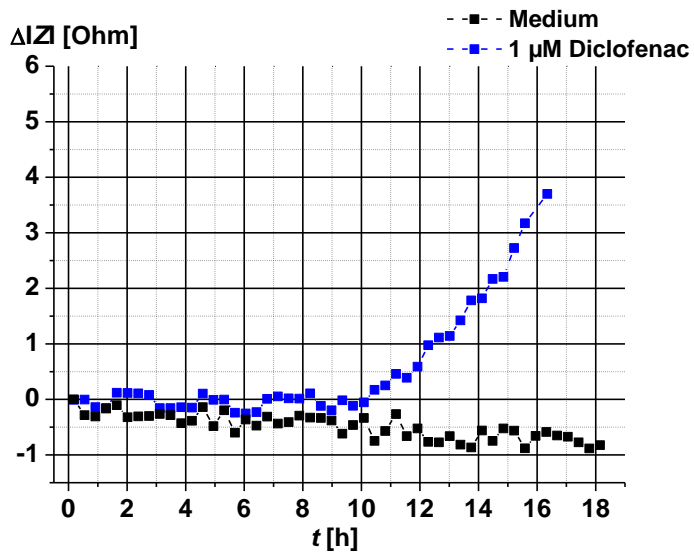

Fig. 8. Change of the impedance modulus at a frequency of $100 \mathrm{kHz}$ for immobilized yeast cells in the medium and in $1 \mu \mathrm{M}$ diclofenac solution

Such a sensor model based on electrical networks is able to describes the dynamic behavior of immobilized cells and the transport processes at the electrodes. Figure 9 shows the equivalent circuit diagram, whose parameters (Table 1) were adapted to the measured data determined by means of a corresponding ITO electrode configuration.

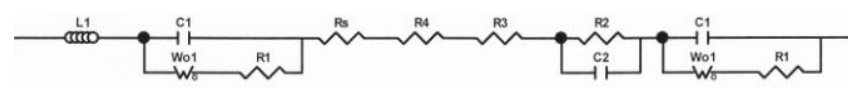

Fig. 9. Equivalent circuit diagram of the cell including the experimental setup (explanation in the text)

Table 1. Parameters of the network model of Fig. 9

\begin{tabular}{|c|c|c|c|}
\hline \multirow{2}{*}{ Parameter } & \multicolumn{2}{|c|}{ Immobilized cells } & \multirow{2}{*}{ Unit } \\
\cline { 2 - 3 }$L_{1}$ & 2 finger & electrode array & \multirow{2}{*}{$\mathrm{H}$} \\
\hline$C_{1}$ & $6 \cdot 10^{-8}$ & $9 \cdot 10^{-8}$ & $\mathrm{~F}$ \\
\hline$R_{\mathrm{W}}$ & $6,5 \cdot 10^{-3}$ & $6 \cdot 10^{-8}$ & $\Omega$ \\
\hline$\tau$ & $1,2 \cdot 10^{-10}$ & $2,4 \cdot 10^{-9}$ & $\mathrm{~s}$ \\
\hline$P$ & 0,42 & 0,46 & \\
\hline$R_{1}$ & $2,5 \cdot 10^{-3}$ & $2,5 \cdot 10^{-3}$ & $\Omega$ \\
\hline$R_{2}$ & 100 & 100 & $\Omega$ \\
\hline$R_{3}$ & 750 & 166 & $\Omega$ \\
\hline$R_{4}$ & 0 & 0 & $\Omega$ \\
\hline$R_{\mathrm{S}}$ & 42 & 42 & $\Omega$ \\
\hline$C_{2}$ & $5 \cdot 10^{-6}$ & $5 \cdot 10^{-6}$ & $\mathrm{~F}$ \\
\hline
\end{tabular}

The behavior of the electrode can be modeled by means of an open Warburg impedance $Z_{\mathrm{W}_{0}}$, a charge transfer resistance $R_{1}$ and a double-layer capacitance $C_{1}$. The cell suspension is described by a RC element (parallel connection of $R_{2}$ and $C_{2}$ ) connected in series with a resistor $R_{\mathrm{S}}$ of the solution. The Warburg impedance models the behavior of transport processes (usually diffusion) to electrodes. It is given by

$$
Z_{W o}=R_{W} \frac{\operatorname{ctnh}\left[(j \tau w)^{P}\right]}{(j \tau w)^{P}}
$$

where $\tau$ is the diffusion time, $w$ the angular frequency, and $j=\sqrt{-1}$ the imaginary unit.

\section{Conclusions}

It was shown that a simultaneous monitoring of optical and impedimetric signals enables inexpensive and robust biosensors based on the whole-cellconcept. Such sensors can be miniaturized and are on-line capable. With further development of the cells towards higher sensitivity (e.g. by an amplification system) and a better signal stability to compare different experiments (e.g. by genomic integration of the PDR5 :: TGFP construct) as well as by the development of a small detection unit to read the fluorescence, in the future such asensor system could contribute to an improved, inline-capable wastewater analysis.

\section{Acknowledgments}

Financial support by the German Federal Ministry of Education and Research is kindly acknowledged (HIGS-03WKCL01F).

\section{References}

[1] Bidoglio G., Contini S., Gawlik B.M., Locoro G., Loos R., Rimaviciute E. EU-wide survey of polar organic persistent pollutants in European river waters. Environmental Pollution 157/2009, 561-568.

[2] Falås P., Jewell K.S., Joss A., Ternes, T.A. Wick A: Transformation of diclofenac in hybrid biofilm-activated sludge processes. Water Research 105/2016, 559-567.

[3] Günther M. et al.: Kombinierter optisch-impedimetrischer Ganzzellbiosensor, 13. Dresdner Sensor-Symposium, Dresden 2017, 120-125.

[4] Lide D.R.: Handbook of chemistry and physics - 83rd edition. CRC Press LLC, 2002-2003.

[5] Meißner M: Arzneimittel in der Umwelt: Natur als Medikamentendeponie, Dtsch Arztebl 105(24)/2008, A-1324 / B-1143 / C-1118.

[6] Pliquett U. et. al.: Schlussbericht. IGF-Vorhaben-Nummer 16925 BR/2; Grundlegende Untersuchungen $\mathrm{zu}$ Miniaturelektrodenarrays für die Impedanzspektroskopische zelluläre Biosensorik.

[7] Schröder M. et al.: Hochintegrierte Ganzzellsensoren für die Umwelt- und Medizintechnik. 13. Dresdner Sensor-Symposium, Dresden 2017, 148-152.

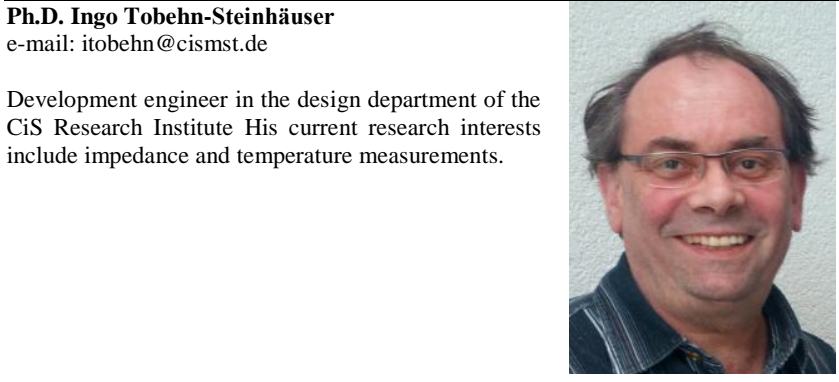

Ph.D. Margarita Günther

e-mail: mguenthe@mail.zih.tu-dresden.de

M.Sc. Eng. Stefan Görlandt

e-mail: sgoerlandt@ cismst.de

M.Sc. Eng. Steffen Herbst

e-mail: sherbst@cismst.de

Ph.D. Heike Wünscher

e-mail: hwuenscher@cismst.de

Prof. Thomas Ortlepp

e-mail: tortlepp@cismst.de

Prof. Gerald Gerlach

e-mail: gerald.gerlach@tu-dresden.de

otrzymano/received: 08.12.2017 